NEWS

\title{
US progressives fight for a voice in bioethics
}

\section{WASHINGTON DC}

Conservative bioethicists often provide intellectual ammunition for US politicians on major issues ranging from stem-cell research to right-to-die decisions. Now several prominent researchers are joining forces to promote different scientific values in public debate.

Arguing that conservative bioethics is out of step with most Americans, the group is forming a 'progressive' movement to influence discussions of scientific and medical topics. "It is important for progressive bioethics to enter the political fray," says Arthur Caplan, an ethicist at the University of Pennsylvania, Philadelphia.

On 3 October, members of the group set out key elements of their approach at a meeting at the Center for American Progress, a leftleaning think-tank in Washington DC that is helping to start the movement. They define themselves in part by what they oppose: the conservative stance embraced by Republican political leaders, by right-leaning think-tanks, and by the President's Council on Bioethics under Leon Kass, who led the council until 1 October (see Nature 437, 307; 2005).

But the progressive group hopes to emulate the conservatives' success in influencing public policy. Conservative bioethicists have set up a network of think-tanks and journals that issue position papers, book media appearances and hold meetings with politicians.

These strategies have shaped the Republican response in debates over stem-cell research and the right-to-die case of Florida's Terri Schiavo. Caplan and others were outraged when Republican leaders fought to keep Schiavo on life support against her husband's wishes. "Nothing could make clearer the difference between progressive and conservative bioethics," says Caplan.

Ethicists at the meeting say that their approach is optimistic about science and technology. "Progressive bioethics opens itself to change," says Alta Charo of the University of Wisconsin, Madison. The conservative approach, they argue, often focuses on how technology could adversely affect the essence of humanity. In a letter accompanying a 2002 report from the President's Council on Bioethics, for example, Kass told the US president that human cloning "carries with it a number of troubling consequences for children, family, and society".

The progressive bioethicists say they plan to study topics not often covered by conservatives - such as inequities in the healthcare system. These inequities were highlighted by Hurricane Katrina, which left thousands of poor African-Americans stranded without federal assistance for almost a week. ${ }^{\alpha}$ Progressive bioethics has to talk about those who are left behind and left out," says Vanessa Gamble of Tuskegee University in Alabama.

And the group hopes to avoid the political missteps that have sometimes resulted from conservative approaches. Public opinion polls found that the Republican efforts to keep Schiavo alive were unpopular. The Schiavo debate may have influenced the Center for American Progress to become more involved in ethics, adds Jonathan Moreno, who was on sabbatical there at the time. "I think they saw that it was useful to have someone like me around to put a different frame on these issues than was being set out by the conservative media," says Moreno, now a fellow at the centre.

Leaders in the progressive-bioethics move-
The Terri Schiawo case polarized opinions on life support and brought bioethics to the forefront of politics.

\section{IMAGE UNAVAILABLE FOR COPYRIGHT REASONS}

ment welcome both Democrats and Republicans, saying they think ethical issues should remain bipartisan. But the group's members have supported positions taken by many Democratic politicians. And the president of the Center for American Progress, John

\section{IMAGE UNAVAILABLE FOR COPYRIGHT REASONS}

\section{Nobel leader - Mohamed ElBaradei}

Of all the Nobel prizes, the award for peace is the most political. After France resumed nuclear testing in June 1995, the Nobel committee awarded that year's prize to nuclear disarmament campaigner Joseph Rotblat and his creation, the Pugwash Conferences on Science and World Affairs.
The $\mathbf{2 0 0 5}$ choice, say nuclear-policy experts, is equally entrenched in politics.

The winners, announced on 7 October, are the International Atomic Energy Agency (IAEA) and its director, Mohamed ElBaradei. Although the agency is tasked with impartiality while monitoring the potential spread of nuclear weapons, it has been at the centre of political disputes involving Iraq and Iran. Observers say that the prize is a signal from the Nobel committee that the agency has maintained neutrality during these rows.

Before the Iraq war, IAEA staff said there was no evidence for an ongoing nuclearweapons programme in the country, a view vindicated by coalition inspectors after the war began. The agency is asking for more 


\section{IMAGE UNAVAILABLE FOR COPYRIGHT REASONS}

Podesta, is a key Democratic strategist who served as chief of staff when Bill Clinton was president of the United States.

“There's a need to re-establish the scientific voice as a voice of fact and reason in the public dialogue," claims Podesta.
But even he isn't sure whether bioethical issues are important enough to sway the votes of Americans. That, he says, "is a political question that will work itself out over the next couple of years".

Erika Check time to continue its work in Iran, but fears that its inspections may be curtailed because of US demands to refer Iran to the United Nations security council.

“This year's prize is clearly intended as a signal of support for multilateral diplomacy and inspections, rather than the use of military force," says Rebecca Johnson, director of the Acronym Institute for Disarmament Diplomacy in London.

The award was also a major boost for IAEA scientists who inspect nuclear facilities. Spokeswoman Melissa Fleming says that staff at the agency's Vienna headquarters were shocked and then jubilant on hearing of the award. ElBaradei had taken the day off, but hurried into the office after hearing of his prize on television news.

Is the award likely to result in anything more permanent than a glow of pride? Fleming is cautious, but says that the prize will at least make it harder for countries to ignore ElBaradei's pleas for more funding. The agency has what ElBaradei calls a "shoestring" inspection budget of US $\$ 100$ million a year.

Others suggest that the award could strengthen the IAEA's position in arguments about whether inspections, or tougher measures such as sanctions or military force, are the best way to deal with countries with alleged nudear-weapons ambitions. But that is wishful thinking given the current US government's antipathy towards ElBaradei, says Michael Levi, an armscontrol expert at King's College London. "The award is not going to change the credibility of the IAEA in the United States," he says. "The people who don't like the agency don't like the Nobel Peace Prize." Jim Giles

See Editorial, page 927.
ON THE RECORD

'We're uplifted. But they told us there were going to be free drinks, and there aren't any."

Amember of $s$ taff at the international Atomic Energy Agency reacts after the organization wins the Nobel Peace Prize.

"My discoveries are 40 years old, and I am an old man."

Chemist Yves Chauvin describes why he felt "embarrassment, not joy" on winning the Nobel prize.

Source: Nature, Der Spiegel

\section{SCORECARD}

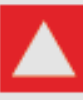

Adult stem cells The Catholic Churchin South Korea has found a way to avoid controversy over embryonic stem-cell research. It is planning to spend US $\$ 10$ million on adult stem-cellstudies.

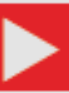

Birdflu

ASan Diego entrepreneur may ruffle feathers with line of avian flu-themed clothing. Among the offerings: a 'Bird Flu Tour' T-shirtand baseballcaps sporting the logo 'Pandemic Fever - Catch It!"

\section{OVERHYPED}

Abstinence-only education US health officials in the Bush administration say avoiding sex is good, but Representative Henry Waxman (Democrat, California) isn't convinced by their reasoning. Last week, Waxman charged that the National Abstinence Clearinghouse - the main group set up to evaluate abstinencepromoting programmes - is scientifically unsound. He cited several of the group's official statements, including:

"Sex therapists consider mas turbation the first stage of sexual addiction for sex addicts."

"Pictures of external genitalia in any form, whether diseased or healthy, can be detrimental to the health of young men and women's minds."

The clearinghouse's stated goal is to "promote the appreciation for and practice of sexual abstinence". 